CZU:811.135.1(478)(091)

https://doi.org/10.52505/filomod.2021.15.04

\title{
LIMBA „MOLDOVENEASCĂ” DIN PERIOADA COMUNISTĂ POSTBELICĂ - EXEMPLU DE TRANSPUNERE ÎN PRACTICĂ A LIMBII DE LEMN
}

\author{
LILIANA BOTNARI \\ Institutul de Filologie Română „B. P.-Hasdeu” al MEC
}

\begin{abstract}
Rezumat. Glotonimul „limbă moldovenească”, promovat pe larg în perioada comunistă postbelică, constituia, de fapt, pârghia de legalizare a existenței a două limbi diferite, de anihilare a conștiinței lingvistice a cetățenilor basarabeni. In acest sens, „extinderea" inventarului de unități lexicale noi formate, în baza limbii ruse, precum și a sensurilor acestora și împroprietărirea lor în vocabularul fundamental al limbii a constituit scopul primordial al autorilor politici comuniști. Toate aceste stratageme de ,implementare" a unei noi limbi, diferită de română, se puneau în aplicare prin gramatici, manualele școlare elaborate sub controlul riguros al ideologiei, prin intermediul presei periodice, a anumitor cotidiane, care deveniseră practic unica sursă de informare a populației. Articolele din presa postbelică reprezentau un soi de programe politice și ideologice, cu un înalt grad de intenționalitate, diseminând, printr-un limbaj sărac, redus la repetiții și tautologii, interesele politice și de expansiune ale autorităților sovietice.

Astfel, limba epocii comuniste din perioada postbelică de pe teritoriul basarabean reprezintă un exemplu perfect de transpunere în practică a noțiunii limbă de lemn.

Cuvinte-cheie: limbă „moldovenească”, limbă de lemn, arie semantică, manipulare, clișeu lingvistic.
\end{abstract}

Abstract. The gluttony „Moldovian” language, widely promoted in the post-war communist period, was, in fact, the legalization key of the existence of two different languages, a tentative to annihilate the linguistic consciousness of Bessarabian citizens. In this sense, the „expansion" of the inventory of newly formed lexical units, based on the Russian language, as well as the spread of their meanings and their ownership in the fundamental vocabulary of the language was the primary goal of communist political authors. All these strategies of ,implementation" of a new language, different from Romanian, were applied through grammars, textbooks edited under the strict control of the ideology, through the periodical press which had become the only source of information for the population. The post-war press articles represented a kind of political and ideological program, with a high degree of intentionality, disseminating, through a poor language, reduced to repetitions and tautologies, the political and expansionist interests of the Soviet authorities.

Thus, the language of the post-war communist era on the Bessarabian territory represents a perfect example of the notion wooden language.

Keywords: „Moldovian” language, wooden language, semantic area, manipulation, linguistic cliché. 
O limbă capătă statut de limbă independentă atunci când întrunește anumite criterii, criteriul inteligibilității reciproce, criteriul de distribuire teritorială a unei limbi, criteriul conștiinței vorbitorilor, criteriul existenței unei limbi comune etc., ce determină gradul de autonomie al acesteia, dar și acestea, în mod separat, sunt inconsistente, neconstituind întotdeauna o bază valabilă. Prin urmare, o varietate de limbă nu poate obține statut de limbă autonomă, dacă nu are, în primul rând, o formă scrisă, normată, proprie, dacă nu e standardizată în gramatici. Doar atunci două limbi pot fi considerate entități separate.

În acest sens, Nicolae Mătcaș constata: „limba literară moldovenească şi limba literară română, deşi sunt denumite în mod diferit, fapt istoriceşte explicabil, e una şi aceeaşi limbă, creată prin eforturile oamenilor de cultură şi ale scriitorilor din Moldova şi Muntenia." (Mătcaș, 2011, p. 62).

Drept argumente pro, autorul enumeră: imposibilitatea alcătuirii dicţionarelor moldovenesc-român sau român-moldovenesc, dacă facem abstracție de așa-zisul dicționar al lui Vasile Stati, Dicționar moldovenescromânesc, care nu este altceva decât o încercare absurdă de a justifica glotonimul de ,limbă moldovenească”, o ,parodie lexicografică” (Dumistrăcel, 2018, p. 17); comunitatea fondului lexical de bază, a foneticii şi, mai ales, a gramaticii; comunicarea fără translatori; editarea fără niciun fel de schimbări a operelor scriitorilor moldoveni în România şi ale scriitorilor români în Moldova. Unica deosebire, susține Nicolae Mătcaș, ,,după cum au menţionat, pe bună dreptate, încă în anii ' 50 eminenţii savanţi sovietici R. A. Budagov şi S. B. Bernstein, este grafia, alfabetul." (idem). Actualmente, și acest aspect este abolit, în Republica Moldova scriindu-se cu alfabet latin.

În aceeași arenă conceptuală de idei se situează lingvista Ariadna Ştefănescu $(2016$, p. 35-36) care interpretează relaţia dintre limba română şi „limba moldovenească” sub câteva aspecte:

1) ca o relaţie dintre un hiperonim - limba română şi un hiponim aşa-numita ,limbă moldovenească”, ,graiul local”, deci unul dintre graiurile dacoromânei.

2) ca o relaţie de sinonimie, interpretare prezentă în cultura basarabeană la începutul secolului al XIX-lea, care nu era deloc în concordanță cu opinia regimului ţarist, or, în cazul respectiv, nu ar mai fi nevoie de glotonimul ,limbă moldovenească", dat fiind faptul că ar putea fi înlocuit cu cel de limbă română/ rumână.

3) ca „o falsă relaţie semantică de diferență netă” - din perspectiva acestui aspect, „limba moldovenească” ar fi „o altă limbă romanică, diferită de limba română”. Promovarea acestei interpretări nu a făcut altceva decât să ,accentueze în societatea basarabeană problemele identitare, cât şi problemele de normare a limbii”, consideră Ariadna Ştefănescu.

Anume acest ultim aspect constituie punctul disensiunii de la care au pornit toate ipotezele referitoare la funcționarea a două limbi diferite: română 
și „moldovenească”. De fapt, aceste două teritorii românofone, România și Republica Moldova, sunt opuse unul altuia în baza contactului istoric al limbii române de pe teritoriul moldovenesc cu limba rusă, o diglosie care a dus la distribuția inegală a funcțiilor limbii române și a celor ale limbii ruse pe teritoriul basarabean în perioada anilor 1940-1941 și 1941-1989, ceea ce a generat stagnarea și ,paralizarea” temporară a procesului de evoluție a limbii române [moldovenești] din Basarabia.

Fiind preocupat de funcționarea limbii române pe teritoriul Moldovei istorice, care cuprindea nu doar teritoriul basarabean, Klaus Bochmann afirma că „,cele două teritorii românofone (Republica Moldova şi partea moldovenească a României) se disting în primul rând prin situaţia macro-sociolingvistică: monolingvismul părţii moldoveneşti a României se opune bi- sau multilingvismului basarabean; diglosiei - deocamdată mai mult ipotetică dintre limba literară şi varietatea românei ieşene i se contrapune distribuţia inegală şi controversat discutată a funcţiilor socioculturale ale românei, rusei şi câteodată ale altor limbi din Republica Moldova." (Bochmann, 2002, p. 10). Astfel, sfera utilizării limbii moldoveneşti în perioada anilor postbelici a fost redusă ,în numele internaţionalismului”, al prieteniei și al colaborării de succes cu poporul rus, al conlucrării în edificarea unui viitor luminos, similar prezentului din Uniunea Sovietică.

O definiție a „limbii moldovenești” ne-o propune Eugenia Bojoga în Limba română - ,între paranteze”, afirmând că „limba moldovenească este un construct stalinist, care are la bază ideea vehiculată de Proletcult a unei limbi simple/simpliste, proletare. Ea nu este altceva decât o română cu un vocabular extrem de redus și rusificat, cu o sintaxă rudimentară (...) și scrisă cu grafie chirilică” (Bojoga, 2013, p. 18). Toate aceste particularități enumerate de către autoare au fost induse în mod artificial și conștient, pentru a legaliza existența a două limbi diferite, pentru a anihila conștiința lingvistică a cetățenilor basarabeni.

Lingvistul Eugeniu Coșeriu pune în evidență natura istorică a limbii, proprietatea ei de a varia: ,considerată în două momente succesive ale istoriei sale, o limbă nu este «ni tout à fait une autre, ni tout à fait la même». Însă faptul că se menţine parţial identică cu ea însăşi şi că încorporează tradiţii noi este, tocmai, ceea ce asigură funcţionalitatea ei ca limbă şi caracterul ei de obiect istoric. Un obiect istoric există ca atare numai dacă este, în acelaşi timp, permanenţă şi succesiune.” (Coşeriu, 1997, p. 247). În acest context, este lesne de înțeles că limba română actuală diferă într-o anumită măsură de cea din perioada inter- și postbelică. Astăzi avem o limbă română care în anii '40-' 80 , prin presiunea cenzurii politice, prin controlul riguros al textelor publicate, a fost „moldovenizată”, suprimată, uniformizată și ,înlemnită” în stil totalitar, dogmatic, însă care, actualmente, încearcă să se racordeze la normele literare valabile şi pe celălalt mal al Prutului, ne referim aici, mai ales, la aspectul informal al limbii, adică la cel vorbit. Or, ,extinderea” inventarului de unități 
lexicale noi formate, în baza limbii ruse, precum și a sensurilor acestora și împroprietărirea lor în vocabularul fundamental al limbii a constituit scopul primordial al puterii sovietice, care se punea în aplicare nu doar prin gramaticile elaborate sub controlul riguros al ideologiei, dar și prin propaganda dusă prin intermediul presei periodice, al anumitor ziare, care deveniseră practic unica sursă de informare a populației.

În aceste circumstanțe istorice vitrege și imprevizibile, perioada regimului sovietic de după al doilea război mondial se caracterizează printr-o activitate asiduă a unui „creier” propagandistic centralizat atât în instituțiile administrative, cât și în cele culturale, de învățământ și religioase. Informarea în masă, moldovenizarea și sovietizarea se efectuau pe diferite filiere, un rol catalizator avându-l presa, care nu mai deținea o funcție exclusiv mediatică, ci căpătă și una politică, devenind un instrument de manipulare și de realizare a obiectivelor forțelor politice. Anume prin intermediul presei periodice, poporul basarabean era pus la curent cu organizarea socială corectă, cu adevărata sa identitate, istorie și limbă, cu „bunăvoința” poporului rus și cu beneficiul comunismului asupra vieții lor sociale.

Limba epocii comuniste, limba presei și a discursurilor difuzate la radio și Tv în perioada postbelică pe teritoriul basarabean reprezintă un exemplu perfect de transpunere în practică a noțiunii limbă de lemn, care se atestă pentru prima dată în romanele scriitorului englez George Orwell (Orwell, 2014). Ulterior, termenul capătă popularitate, fiind preluat sub diverse denominatiii calchiate: langue de bois - care pentru lingviștii francezii Joanna Nowicki și Michaël Oustinoff reprezintă un limbaj „,ce impune o anumită viziune asupra lumii, o decriptare a realității formatate, care adesea este chiar inversată în slujba unei puteri care astfel își găsește legitimarea și urmărește scopul nu de a comunica, ci de a împiedica comunicarea adevărată, de a bloca controversa din spațiul public fără puteri compensatorii autentice" (Nowicki, 2015, p. 201207) -, wooden language, newspeak, noulimba sau limbaj de lemn. În spațiul românesc, fenomenul desemnează limbajul regimului politic comunist din perioada sovietică postbelică. Însă această limbă de lemn a regimului sovietic se extinde dincolo de spațiul politic, devenind limba unică a presei, a televiziunii și a radioului, a relaţiilor administrative și chiar o limbă clișeizată a tuturor. Prin utilizarea acestei limbi, se urmărea propaganda și monopolizarea gândirii comunitătii basarabene, cenzura și realizarea obiectivelor politice, îngustarea orizontului de percepție a realității, manipularea și uniformizarea poporului derutat de schimbări, menținerea acestuia în obediență și ne (-)știință.

Limba de lemn este cercetată de către Tatiana Slama-Cazacu care o definește drept un ,subsistem al unei limbi, desemnând mai ales elementele lexicale, dar și unități frazeologice, cu caracter de expresii fixe, de clișee încremenite, cu sens determinat în contextul unei anumite «autorități», în mare măsură utilizate stereotip-dogmatic" (Slama-Cazacu, XXIV, p. 4). Specificul limbii de lemn se caracterizează prin unele particularități fonetice, 
morfo-sintactice și lexicale specifice, dar de cele mai multe ori și prin lipsa unui autor: articolele, discursurile scrise ale presei periodice comuniste, sub amprenta limbii de lemn, mai ales cele de pe primele pagini, nu erau întotdeauna semnate de către vreun autor sau jurnalist, fiind minuțios redactate în prealabil și șlefuite să corespundă standardelor programului ideologic și strategic.

În lucrarea „Limbaj și politică”, Rodica Zafiu (2007) distinge două ipostaze principale în care poate să apară limba de lemn: ca desemnare denotativă, fiind specifică limbajului politic al regimurilor totalitare comuniste și ca desemnare calificativă, evaluativă a limbajelor politice considerate ca excesiv birocratizate, clișeizate etc. Mai mult, lingvista remarcă proprietatea limbii de lemn de a varia în funcție de perioada istorică - ,de la un limbaj mai violent și mai influențat de rusă, în faza de impunere a regimului - la unul conservator, ceremonios, euforic, cu accente mistic-naționaliste, în faza de stabilitate" (Zafiu, 2007, p. 47). Aderăm la părerea lingvistei și completăm că, de fapt, noțiunea limbă de lemn reprezintă limba regimului comunist și doctrinar din perioada de după al doilea război mondial, care, în timp, s-a resemantizat, extinzându-și aria semantică și vizând nu doar acea limbă de lemn, ci și limbajul ideologic al partidelor politice din prezent, care abundă în clișee și construcții lexicale ce se repetă în toate discursurile, devenind o nouă limbă de lemn, cu conotații nu tocmai pozitive.

Pentru arealul rus, limba de lemn [деревянный язык] este caracterizată prin ,stereotip, secundaritate, pseudosciență, eufemizare, demagogie”(Шульц, 2015), elemente care o transformă cu ușurință în ,instrumentul verbal pentru manipularea conștiinței publice”, consideră V. L. Șulț și T. M. Liubimova.

În opinia noastră, limba de lemn apare ca un produs al unor schimbări sociopolitice iminente, fiind o limbă rigidă, clișeizată și ideologizată, care servește drept instrument de manipulare și distorsionare a realității, în serviciul obiectivelor politice ale unui regim totalitar instaurat. Manipularea prin comunicare devine ,arma” autorilor comuniști, prin care se încearcă o re-educare a populației, o reducere la obediență și o asimilare de către aceasta a noilor norme, credințe, valori, conduite și chiar idei, gânduri, demne de un „homo sovieticus” adevărat.

Analizând limbajul presei comuniste sovietice, subiectele promovate de cele mai dese ori, (non-)stilul de a scrie al autorilor, observăm că limba presei periodice din Basarabia postbelică este un exemplu clasic al „limbii de lemn”.

Corpusul de referință pe baza căruia s-a constituit cercetarea de față cuprinde articole şi discursuri politice selectate din câteva numere ale revistei Moldova socialistă editată în anul 1946, exact după reocuparea Basarabiei în 1944, atunci când discursurile ideologice, sloganurile politice și informațiile difuzate erau cele mai ,pline de suflul comunist”, unele din 1965, perioada de până la reforma ortografică din 1967, și altele - din 1976. Paralel, am consultat și unele numere ale revistelor Tineretul Moldovei și Scânteia leninistă, care aveau același caracter reformator. Articolele ziarelor din perioada postbelică 
reprezentau un soi de programe politice și ideologice, cu un înalt grad de intenționalitate și caracter disimulant, diseminând, printr-un limbaj sărac, clișeizat, interesele politice și de expansiune ale autorităților sovietice, indicându-se anumite conduite pe care urmau să le prezinte cu docilitate, drept răspuns-comportament, auditoriul vizat.

Efectuând o analiză strict lingvistică sau, mai larg, semiotică a titlurilor din presa periodică a anilor 1944-1960 (Botnari, 2019), observăm că acestea, prin formele și strategiile de intitulare, reprezintă intențiile și obiectivele de partid, promovând teme de ordin cotidian, care ar trebui să constituie sfera de interes a publicului larg, prin utilizarea unei catene de verbe mobilizatoare, prin opoziții adjectivale între „mai mult” sau „mai puțin”, prin construcții impersonale sau imperative, prin sensuri ambigue și greu de „digerat” de mintea și așa confuză a maselor: De grăbit predarea pânii la stat (Moldova socialistă, 18 iulie 1946, № 139); De reorganizat radical lucrul industriei materialelor de zâdire (Moldova socialistă, 23 iulie 1946, № 143); La zavod s'a discutat planul lucrărilor mari (Moldova socialistă, 6 aprilie 1946, № 69); Îs sămănate 1500 hectare de popuşoi (Moldova socialistă, 13 aprilie 1946, № 74); Oamenii să fie liberi de rămășițele trecutului (Moldova socialistă, 18 decembrie 1965, № 243); „Mărunțișuri” ce trebuiesc lichidate (Moldova socialistă, 17 iunie 1976, № 140); Vom realiza două planuri (Moldova socialistă, 22 iulie 1965, № 170); Vom munci și mai bine (Moldova socialistă, 14 noiembrie 1976, № 266) etc.

F. Thom, în lucrarea „Limba de lemn” (Thom, 1993), prezintă o analiză detaliată a caracteristicilor esențiale prin care putem califica un anumit discurs ca fiind ,supus” limbii de lemn a presei sovietice. Autoarea menționează nonstilul limbii de lemn, apelând la cele câteva calități ,,indispensabile stilului bun" enumerate de către Aristotel: claritatea - or, discursurile politice și articolele bine lustruite din Moldova socialistă, Scânteia leninistă a anilor 1946-1976 sunt clare doar pentru omul sovietic, care trăiește și respiră ideologia comunistă; adecvarea - textul trebuie să fie adecvat cititorului, însă textele cercetate sunt plate, scrise în aceeași cheie, cu utilizarea aceluiași vocabular sec și repetitiv; invenția - „discursul trebuie să surprindă, să cuprindă ceva neașteptat pentru a menține atenția auditoriului” (ibidem, p. 72); textele ideologice nu lasă loc imaginației individuale, realităţile sovietice sunt redate în mod rigid, printr-un inventar de cuvinte arhicunoscute, apelânduse, de cele mai multe ori, la serii sinonimice sau, pur și simplu, la repetiții, tautologii ale acelorași construcții-clișeu pline de emfază și incongruență. Astfel, vocabularul discursurilor presei de partid a anilor 1946-1989 denotă un șir de particularități specifice, incluzând un inventar considerabil de arhaisme lexicale, de împrumuturi din rusă, cu conservarea formei de origine sau cu adaptarea acesteia la „limba moldovenească”, de calchieri lexicale, gramaticale sau semantice, în diverse construcții pleonastice, în comparații și metafore, în hiperbolizări și formațiuni antitetice etc. Lexicul presei cotidianelor consultate 
cuprinde termeni care corespund unor concepte social-politice ale vremii, specifici perioadei sovietice: arhaisme și forme învechite ale unor cuvinte, precum și împrumuturi din rusă sau ,actualizări” ale unor cuvinte preluate din slavă: peatiletcă (Planul peatiletnicii noi al Republicii Moldovenești), brigadă (Brigada de tractoare a lui Fiodor Corotenco), zavod (Zavodul se restabilește), voczal (Când va fi zâdit voczalul din Chișinău?), temp (Să grăbim tempurile sămănatului tuturor culturilor), norodnic (Despre planul de cinci ani al restabilirii și dizvoltării gospodăriei norodnice a RSS Moldovenești pe anii 1946-1950), comsomolist (Comsomolisstii au remontat şcoala), colhoz (Vlagă pentru lanurile colhoznice), trudozî (Șepte kilograme pâne pe trudozî) etc. Paradigmele lexicale formate în jurul cuvintelor dezvoltare, progres, zidire, creștere se repetă periodic în text, în aceleași circumstanțe semantice, redând aceeași idee, cu o variație lexicală ușoară și redundantă. Autorii discursurilor politice consultate în presa comunistă postbelică își recrutează inventarul lexical din sfera socialului: clasă, egalitate, colectivitate; din sfera economică: industrializare, progres, gospodărie obștească, construcție socialistă; din sfera agrară: muncă, cincinal, colhoz, brigadă, truditor etc.

Astfel, cenzura trasează granițele limbajului, dirijează selecția anumitor mijloace de exprimare - autorii discursurilor politice și ai articolelor politizate se autocenzurau, impunându-și limite, suprimându-și opiniile sau ideile referitoare la realitate, la conducere, în virtutea rigorilor impuse de politica partidului. Despre acest aspect al scriiturii specifice presei comuniste ne aduce mărturii Emilia Șercan, prin intermediul unui fost ziarist al ziarului Scânteia din România anilor regimului comunist:

„Știai că nu ai voie să scrii despre dragoste, ci numai despre dragostea dintre mamă și fiică, nu despre Eros, erotică. Să eviți cuvântul «cimitir» - că pe tovarășul îl deranjează -, să eviți cuvântul «cruce», să eviți să lauzi prea mult o femeie - că naște invidia tovarășei. Adică lumea știa că erau niște tabuuri. Erau tabuuri de tematică, un întreg vocabular de cuvinte care nu plăceau, fără neologisme, împrumuturile astea străine. Exista o grilă, pe care se punea foarte răspicat accentul" (Șercan, 2015).

Afluxul de cuvinte derivate sau împrumutate din limba rusă ilustrează perfect procesul de moldovenizare demarat de puterea sovietică, rezultat direct al contextului politico-istoric din perioada de după 1944. Prin urmare, în anii 1944-1960, presa periodică este una care promovează agresiv ideologia comunistă, valorile sovietice și care militează cu înverșunare pentru „adevărul” comunist, pentru asigurarea ordinii interne și pentru „hărnicirea obștii”. Locutorul politic manipulează, ascunde, falsifică pentru a transforma colectivitatea într-o masă pasivă, dar în același timp, maleabilă, docilă, gata să slujească crezului comunist și normelor de muncă zilnice.

$\mathrm{Nu}$ putem afirma că din 1960 situația se schimbă considerabil. Elena Negru și Gheorghe Negru (Negru, 2019) notează că în preambulul hotărârii CC al PCM Despre literatura care vine în republică din străinătate din 1 februarie 
1966 se arăta, printre altele, că în multe dintre publicațiile ce intrau în RSSM era falsificată realitatea, iar acest fapt „,dezorienta oamenii muncii din republică”, influența „,negativ asupra formării unei concepții veridice despre lume în rândul populației republicii, mai cu seamă în rândul tinerilor”, crea „confuzie în mințile lor”, „dădea naștere dispozițiilor nesănătoase”. Totuși, analizând inventarul de termeni arhaici sau al celor împrumutați din rusă, depistați în cotidianul din 1965, observăm că acesta este mult mai redus decât cel din 1946, fapt ce denotă că „limba moldovenească” cunoștea o oarecare evoluție, o dezvoltare, chiar dacă insignifiantă, fiind atestate și unele cuvinte neologice pentru acea perioadă: rentabil (E rentabil? Da!); asolament (Sămânța şi asolamentul. Câteva sujestii); șoc (Secerișul - front de șoc!); transfigurare (Transfigurare); miting (Mitingul soveto-vietnamez); anatomopatolog ( $S^{\prime}$ a incheiat congresul anatomopatolojilor); eșalon (Eșaloane tiraspolene) ș.a.

Cele menționate anterior ne justifică să afirmăm că limbajul presei periodice din 1944-1960 este un limbaj clișeizat, stereotip, care se precipită în jurul unor probleme ce vizau mai ales populația rurală și clasa muncitoare, fiind cosmetizată realitatea și intențiile politice, iar din 1965, apar tot mai des discursuri ale liderilor de partid și de stat, precum și diverse rapoarte ale congreselor, prin care autorii comuniști se arată îngrijorați și critică intensificarea problemei naționale de pe teritoriul basarabean. În uzul actual al limbii arhaismele lexicale și cele semantice, cuvintele rusești au fost substituite corespunzător cu echivalente românești. Unitățile lexicale precum: soviet, colhoz, pionier, cincinal (peatiletcă), comsomol etc., termeni ce se refereau la realităţi cu specific istorico-politic, la administrația de stat sau la cea economică a uniunii sovietice, au căpătat funcții evocative, devenind niște indici diacronici sau diatopici, care ne permit să identificăm un text sau un context semantic aparținând limbii române din perioada regimului socialist sau graiului moldovenesc de pe teritoriul Republicii Moldova.

În pofida tuturor fonetismelor și construcțiilor lexicale împrumutate sau calchiate din rusă, formarea unei limbi „moldovenești” nu s-a reușit, aceasta fiind mereu limba română standard, scrisă cu alfabet chirilic.

\section{Referințe bibliografice:}

1. BOCHMANN, Kl., DUMBRAVA, V. Limba română vorbită în Moldova istorică. Vol. I. Leipzig: Leipziger Universitätsverlag, 2002. 202 p. ISBN 3-936522-08-1.

2. BOJOGA, E. Limba română - ,între paranteze”?: despre statutul actual al limbii române în Republica Moldova. Chișinău: Editura Arc, 2013. 248 p. ISBN 9789975617536.

3. BOTNARI, L. Limba presei comuniste a anilor 1944-1980. Particularități morfo-sintactice. În: Filologia Modernă: realizări și perspective în context european. Spiritus loci: interferențe, confluență, rezistență. 10-11 octombrie 2019, ediția a XIII-a, Chișinău: Pro Libra, pp. 25-33. ISBN 978-9975-3289-6-8. 
4. COȘERIU, E. Sincronie, diacronie și istorie. Problema schimbării lingvistice. Versiune în limba română de N. SARAMÁNDU. București: Editura Enciclopedică, 1997. p. 254. ISBN 973-45-0203-4.

5. DUMISTRĂCEL, S. Știința varietății lingvistice diatopice în sprijinul unității naționale de la Weigand la Pușcariu - Pop - Petrovici. În: Limba Română. 2018, nr. 7-8 (249-250), p. 9-58. ISSN 0235-9111.

6. MĂTCAȘ, N. Calvarul limbii române din Basarabia: Studii. Articole. Comunicări. În: MĂTCAȘ, N., BANTOȘ, Al. Limba română. Chișinău: Limba Română, 2011. 552 p. ISBN 978-9975-9937-1-5.

7. NEGRU, E., NEGRU, Gh. Autoritățile sovietice în război cu presa și literatura din Republica Socialistă România. În: Limba Română. Nr. 1, anul XXIX, 2019. pp. 295-306. ISSN 0235-9111.

8. NOWICKI, J., OUSTINOFF, M. La langue de bois, notion clé du monde contemporain [online]. În: Hermès. nr. 71, 2015/1. p. 201-207. [online] Disponibil: https://www.cairn.info/revue-hermes-la-revue-2015-1-page-201.htm\# [citat 09.03.2019]

9. ORWEL, G. O mie nouă sute optezi și patru. Trad. Mihnea Gafița. București: Editura Polirom, 2014. 348 p. ISBN 978-973-46-3202-2.

10. SLAMA-CAZACU, T. Limba de lemn. În: România literară. Nr. 42, an XXIV. p. 4.

11. ȘERCAN, E. Cultul secretului. Mecanismele cenzurii în presa comunistă. Iaşi: Editura Polirom, 2015. 264 p. [online] Disponibil: https://books.google.md/ books?id=VS2TDwAAQBAJ\&pg $=$ PP1\&lpg=PP1\&dq=\%C8\%98ercan+Emilia, + Cultul $+\mathrm{s}$ ecretului. + Mecanismele + cenzurii $+\% \mathrm{C} 3 \% \mathrm{AEn}+$ presa + comunist $\% \mathrm{C} 4 \% 83 . \&$ source $=\mathrm{bl} \& \mathrm{o}$ ts $=$ yyWfzeizU\&sig=ACfU3U0vATJ41pdlOVRvpMhrSGTVGEsMhQ\&hl=ro\&sa=X\&v ed $=2$ ahUKEwja5uiP143mAhXMC-wKHRexAwA4ChDoATACegQIChAB $\# \mathrm{v}=$ onepage $\& \mathrm{q}=\mathrm{c}$ onstr $\% \mathrm{C} 3 \% \mathrm{~A} 2$ ngere $\% 20 \% \mathrm{C} 8 \% 99 \mathrm{i} \% 20$ convingere \&f=false [citat 20.09.2019]

12. ŞTEFÁNESCU, A. Variație și unitate în limba română standard din Basarabia. București: Editura Universităţii din București, 2016. 370 p. ISBN: 978-606-16-0741-9.

13. THOM, F. Limba de lemn. Trad. M. ANTOHI, București: Humanitas, 1993. 245 p. ISBN 973-28-0347-9.

14. ШУЛЬЦ, В. Л., ЛЮБИМОВА, Т. М. «Деревянный язык» как зеркало револючии. 2015. [online] Disponibil: http://socis.isras.ru/files/File/2015/2015_1/ Schulz.pdf [citat 20.09.2019]

Notă: Articolul a fost realizat în cadrul proiectului de cercetare 20.80009.1606.01 Valorificarea științifică a patrimoniului lingvistic național în contextul integrării europene, Institutul de Filologie Română „B. P.-Hasdeu” al MEC. 